\title{
Conservation Identifications on Wooden Structures of the Traditional Dwellings in West Kalimantan
}

\author{
Zairin Zain*, Jawas Dwijo Putro \\ Dept. Architecture \\ Faculty of Engineering Universitas Tanjungpura \\ Pontianak, Indonesia \\ *zairin.zain@untan.ac.id
}

\begin{abstract}
The province of West Kalimantan has many cultural heritage buildings that spread across 12 districts/cities. Those cultural heritage buildings come from three ethnic groups who live in the scattered settlements of West Kalimantan, namely Malay, Dayak, and Chinese. Both historic and traditional buildings are buildings with the main structure made of wooden materials that encounter weather and degradation due to natural conditions or organisms' influence. This article is a preliminary study to compare several research results on the conservation of wooden structures to traditional dwellings as the preservation efforts of cultural heritage architecture in West Kalimantan. Traditional houses in West Kalimantan are generally tens to hundreds of years old and established $1-3$ meters above the ground with poles foundation sunk to a water basis. Because the structure stands buildings on the side of a river with moist soil conditions, it is directly exposed to building sections to temperature and weather. This scientific article is developed by employing the text-in-context method with the qualitative paradigm by compiling the research results related to the investigation of organisms that destroy buildings and cultural heritage structures made of wood. The researcher's configuration of a result data set is assembled into the findings' integrity to answer the research objectives and questions. As a result, wooden materials of cultural heritage in West Kalimantan should be preserved by the chemical compounds, local material of bio pesticides, and traditional methods to preserve decayed structures and ornaments. Friendly preservation by environmental improvement and treated substitute material is also effective in refining the wooden structures.
\end{abstract}

Keywords-identification, heritage, traditional dwellings, conservation, wood structures

\section{INTRODUCTION}

The existence of cultural heritage is important as the learning media for future generations in the understanding of history, science, and culture for the future development of a nation's social life. In this regard, cultural heritage needs to be preserved and managed appropriately through efforts to protect, develop, and utilize it to advance national culture for the greatest prosperity of the people. Cultural heritage objects and buildings contain superior life attitudes and mentality, which were owned by the founding ancestors' community [1].
Cultural heritage objects and buildings become reasoning resources that can provide inspiration and a source of learning for every nation's child in the next generation, including the Indonesian nation. As cultural heritage objects exist in the kind of architecture, it is necessary to preserve traditional architecture [2]. Greatest efforts need to be executed to protect and prevent artifacts from damage to be preserved for future generations. As it is a legacy product from the past, preserving traditional architecture to maintain the authenticity of architectural materials as they were in the past is very challenging to fulfil due to the limitations of certain materials at the time. Additionally, it is also impossible if we only consider maintaining the authenticity of all architectural elements since the construction and architectural materials have been damaged and do not meet current architectural safety requirements $[3,4]$.

Cultural heritage as a national treasure has to keep its importance by socialization and conservation of various stakeholders [5]. Some cultural heritage buildings in Indonesia generally use wood materials on their main structures. Buildings with wooden structures from the past will periodically experience weathering or degradation due to environmental and climatic conditions. Indonesia's climatic conditions are very favourable for biotic and abiotic factors causes serious damage to buildings. Wooden materials from old buildings were usually engaged by wood rot fungi, occurring in a loss of dimensional stability of the building material and structure [6].

West Kalimantan is the location for dozens of Malay sultanate palaces with hundreds of traditional houses and hundreds of Dayak longhouses scattered in many settlements. Distinguished traditional dwellings in West Kalimantan are fundamental as structures with the unique construction of timber materials. These buildings are cultural heritage objects that present some problems in determining the appropriate conservation management to save the cultural heritage architecture of wooden structures. Wooden building structures in Indonesia, as masterpieces rooted in the nature of the multiple ethnic cultures, show diversified architectural features rich in local identity. The abundance and the high cultural value of the historical wooden buildings with unique structures 
and plans should be well protected by the activity of conservation $[3,4]$.

Historical dwellings would connect people with a history from the past and science and development for the future [7]. A proper approach to the conservation of wooden structures is needed to save the architecture of cultural heritage in West Kalimantan Province. A study on cultural heritage buildings' treatment is needed before restoration of the damaged buildings and structures. Efforts to restore some physical conditions occur by employing repairing, strengthening, and/or preserving them through reconstruction, consolidation, rehabilitation, and restoration activities. Different historic buildings' parameters will have different impacts on the preservation of cultural heritage buildings [8]. The proper list of work requirements for handling the heritage buildings is essential in more structured, controlled, and should be carried out by experts.

The strategy of conservation of cultural heritage buildings carried out by the heritage expert team requires beginning with a review of the research approach of the related studies. Wooden structures in cultural heritage buildings in West Kalimantan require identification of the factors that cause damage and degradation to structures and materials. Toward this objective, this article is the initial identification for compiling several research results on building structures with wood materials. The purpose of this scientific article is as a preliminary study towards the conservation of wooden structures in traditional dwellings as an effort to preserve cultural heritage architecture in West Kalimantan.

\section{METHODS}

This scientific article is developed by employing the textin-context method with the qualitative paradigm. This text-incontext method extracts findings from related research articles and includes articles that use mixed research methods and synthesis research studies. The articles' criteria are scientific paper that conducts a review in diagnosing wood as materials of building structures [9]. The articles collect from online sources by keywords constraint to be reviewed over to the conditions found in West Kalimantan's traditional houses. The extraction is determined based on the findings relevant to the purpose and questions in writing. Relevant findings are used as specifications of information found in each presented article and considered as findings. The findings collected from the research issues of various sources related to the purpose of writing will be discussed further to obtain results based on the formulation of the problem and its purpose. The research findings as a qualitative paradigm are the researchers' interpretation of a review of the shown data generated as the text-in-context method's findings. As a result, the researcher's configuration of a data set is assembled into the findings' integrity to answer the research objectives and questions. A conclusion of the study is generated from a complete process of rolling discussion.

\section{RESULTS AND DISCUSSION}

\section{A. Results}

The traditional houses of West Kalimantan are generally established 1 - 3 meters above the ground with poles foundation sunk to a water basis. The houses are generally tens to hundreds of years old, and all stand on the banks of a river with moist soil conditions. Due to times, all buildings have experienced weathering caused by the fungal attack on elements. The condition is directly exposed to building sections to temperature and weather (parts usually are not covered by shade) and parts directly in contact with the soil, such as foundations. The weathering to those parts is often wet due to exposure to river water and wet-dry condition due to weather and temperature influences. The river was the general orientation of traditional dwellings in West Kalimantan in the past [10]. Historically, the design of West Kalimantan's traditional dwellings had some details of the most desirable mitigation features, which made the buildings remain dry from the periodical flood, caused people to live most intimate to nature and living near the slope area [11]. On the other hand, the wetness and dryness conditions in the structures cause the wood material to decay. Indonesia's climate and soil conditions are very supportive of termite life [12].

In severe condition, there were indeed pieces of porous wood around foundation piles. Wood on the inside structures of the house was found decayed by insect attacks.

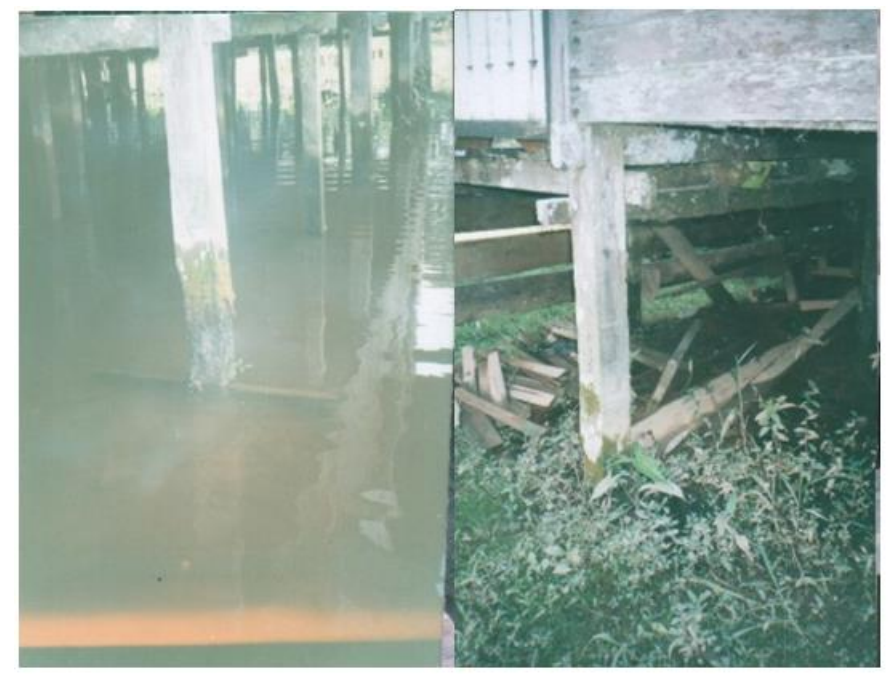

Fig. 1. The condition of wet-dry to the foundation of West Kalimantan's traditional house (the picture taken to the houses in Sambas Town).

The stairs leading to the attics and the floor are porous by the attack of wood powder. This powder insect attack is so intense on the parade that this room is only a place to store unused items. There is also a room partition wall with softwood materials attacked by powdered insects and has become porous. 


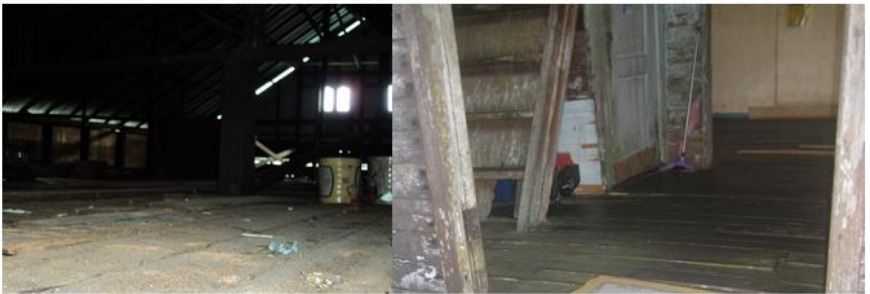

Fig. 2. Powder beetles, fungi, and molds attacks on the stair and attic floor of West Kalimantan's traditional house (the picture taken to the houses in Sambas Town)

The house's outer walls are still in good condition because they use hardwood even though all of them have experienced fungal attacks. No damage on walls was found due to a powder insect attack on this type of hardwood material. Fungal attacks were observed on the floors and fences that covered all sides of the open platform, which all elements were using hardwood materials. The exposed structures on the veranda become porous due to attacks by mould and mildew.
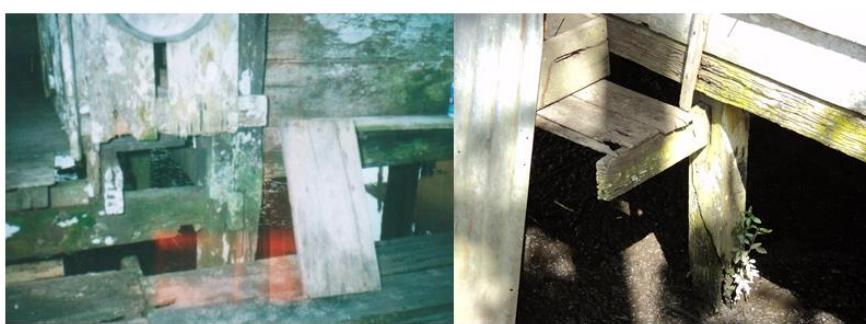

Fig. 3. The mildew attacks the floor joint of West Kalimantan's traditional house (the picture taken of the houses in Sambas Town)

Climatic and weather conditions in West Kalimantan are the factors causing the fracture experienced by wooden buildings. High rainfall, high humidity, strong irradiation, wind speed, and temperature also promote the growth of fungi and insects [13]. Wood-destroying fungi can thrive over a wide temperature range and the parts in contact with the soil are the ones that experience the rapid growth of fungi and insects. The elements of the building that experience weathering are always moist and submerged by water at high tide [13]

On observation of the intensity of termite infestation in the city of Pontianak, reported that old buildings with a construction age of over 31 years are the structures most frequently attacked by termites [14]. On the other hand, the structures with a construction age of below 15 years are found less affected by termites than the construction between 16 and 30 years old. This condition indicates that cultural heritage buildings with climatic and environmental conditions in Pontianak and generally in West Kalimantan are vulnerable to attack by organisms and wood rot fungi. The genetic material for the building structures of Malay traditional dwellings in West Kalimantan was the use of first-class timber, such as Belian [11]. In the meantime, specific material for the support structures used second-class wood such as Jelutung, Selimpau, Rengas, etc. It is found that as many as 10 termite species were detected through a survey conducted on buildings in West Kalimantan, particularly in Pontianak [12]. These species are Nasutitermes Havilandi, Cryptotermes sp.1, Cryptotermes sp.2, Cryptotermes Cynocephalus, Cryptotermes Domesticus, Coptotermes Curvignathus, Coptotermes Kalshoveni, Schedorhinotermes Medioobscurus, and Globitermes Microbial Hamburger.

\section{B. Discusssion}

According to the condition of the traditional houses in West Kalimantan, the listed structural elements to consider to be preserved as follow:

- The decayed structure due to abiotic factors (temperature, weather, sunlight, humidity).

- The degraded support elements such as ornaments, walls, and stairs due to biotic factors (termites, powder beetles, fungi, moulds, bacteria)

It is important to protect wood from decay with preservatives suitable in areas with high humidity conditions throughout the season, due to soil, rainwater, condensation, and infiltrated water [15]. The temperature and amount of precipitation and their distribution throughout the year are climatic factors that affect the amount of decay in weathered wooden exterior structures. The building structures preservation of wooden materials is the natural ability of wood to withstand attacks that cause wood damage, including biotic factors (termites, powder beetles, fungi, molds, bacteria) and abiotic factors (temperature, weather, sunlight, humidity) [16]

Additionally, cultural heritage buildings have also experienced a lot of degradation processes, both weathering or damage due to age and environmental conditions. Wood, as an organic material, can rot and degrade immediately compared to other materials in cultural heritage buildings [17]. Generally, causes to the traditional houses of West Kalimantan, rot and degradation of wood are primary factors for moisture, fungus, insect attack, or fire. Furthermore, wood is actively affected by the relative humidity in the environment, which causes its impact to expand and contract to other elements in the structure of cultural heritage buildings. Damage to the wood on the structural elements of traditional houses in West Kalimantan, either at joints or in other places, is critical to consider because it has a major impact on the structure's load-bearing capacity and strength. According to an analysis, treated wood should be substituted on or near the ground before element restoration of West Kalimantan's traditional houses because the soil is a source of water and actively grows rot fungi [18]. Another suggestion is in making design improvements to structural and construction details, one must be able to direct rainwater or its condensation away from the structure [18]. Damage to the wood in the structure causes a serious loss of strength.

The treatment to prevent most wood rot by keeping the wood dry. Wood rot will not appear in the material if the wood dryness level reaches a moisture content of 6-8 percent for indoor use or 15-18 percent for outdoor use [19]. In other 
words, the rot will not appear if we can keep the moisture content on wood material below 20 percent. The use of wooden materials in building construction necessitates considering this material's ability to withstand weather impacts [15]. According to wood species, to resist degradation by fungi and insects, restoration on building elements of a traditional house in West Kalimantan has to pay attention to a particular wood's properties influence its suitability for a particular use.

Identification of the potential contribution of increased decay of wood related to the climate of a geographic area [15] determine the appropriate assigning measures to define the type and amount of protection required for the various climateaffected building components based on average monthly temperatures and rainfall frequency. This climate index base of measurements can be developed on cultural heritage buildings in West Kalimantan because it has specific geographical and climatic conditions as a tropical area. This index will later classify the types and amounts of protection required for various components of cultural heritage buildings affected by weathering.

The ability of salt to provide durability in wood is worthy of consideration for wood conservation efforts in traditional houses' structural elements in West Kalimantan. Recent research providing insight into the extraordinary durability of wooden foundations [20]. The higher salt content in wood materials may prevent fungal and insect attacks. The injection of higher salt content in wood materials can be considered for wood conservation efforts in traditional houses.

In this preservation effort, modern technology commonly uses chemicals in cultural heritage buildings. Name wood preservatives of the most common types of oil as creosote, pentachlorophenol, and copper naphthenate. Conventional oiltype preservatives, such as creosote solution and pentachlorophenol, are mostly limited to uses that do not require frequent human contact [15]. The use of chemicals with liquid formulas on the traditional houses of West Kalimantan effectively prevents the attack of dry wood termites [21]. Still, it is considered to cause problems due to health and environmental considerations. Subterranean termites are notorious for causing damage to wooden structures, and many efforts have been made to control their growth [22]. This prevention is the condition of structures of house elements suspended to become decay in temporary periods. In the underground, subterranean termites have many food sources in the field, such as building structures or natural food sources. According to this condition, structural and sanitary measures will not provide complete protection against termites, so chemical protection is often used as an option [23].

Therefore, it is important to develop restorative treatments that do not pose an environmental hazard. Local people already have knowledge that has been taught from generation to generation in defeating problems of decreased quality and strength of wood materials for building structures. Of course, this traditional technology may adapt to the surrounding environment because it uses environmentally friendly materials. An ecological approach is an environmentally responsible activity as it limits the use of toxic substances to protect the wood from damage, and efforts to repair damaged conditions in the wood using chemicals are also not recommended [17].

Wood in buildings can rot due to fungi, animals, and woodeating bacteria [17]. Wood can also be damaged through mechanical wear or degraded/decomposed by chemicals. Weathering causes erosion of wood surfaces. Wood degradation is not the same as wood damage [19]. The three main factors of wood degradation are fungi or mold, insects, and weathering. Organisms that can decompose wood have four basic requirements for development: moisture (generally 25 to 100 percent by weight of dry wood), oxygen, temperature (generally between 50 degrees and 95 degrees Fahrenheit), and a food source (the wood itself) [19]. The development of the conservation of cultural heritage buildings using traditional materials and methods in West Kalimantan continues to be developed today. Conservation measures using natural materials and working methods are carried out in accordance with the traditions of local communities in West Kalimantan. Many local wisdom needs have been explored in carrying out the rescue and preventing cultural heritage buildings from experiencing weathering and damage.

Worldwide, there are about 2000 species of termites (Isoptera). Termites are divided into six families [17]. Of these termite species, two important wood destroyers are Rhinotermitidae ('subterranean' termites) and Kalotermitidae ('dry wood' termites). These termites extensively digest polysaccharides in wood, while lignin is also slightly altered (subterranean termites) or partially decomposed (dry wood termites). As a result, termites can destroy wooden structures. Most termites live in tropical and subtropical zones. However, the distribution of these termites extends far into the temperate zone, both in the northern and southern hemispheres. Subterranean termites are notorious for causing damage to wooden structures, and many efforts have been made to control their growth [22]. Today, the use of feed systems with multiple application methods has become a common approach developed commercially. Plant extracts contain a variety of chemical compounds, some of which may have potential uses in agriculture for managing insect pests. Many plants have antitermite properties, such as cloves and cinnamon [22]. Basil is also known for its pest control properties which have many variations, and bay leaves have repellent properties to control structural pests such as termites [22].

The use of bio-based materials in controlling subterranean termites has been observed by many researchers for economic and environmental reasons as well as their potential availability and variability [24]. In research about the prevention of termites in West Kalimantan, extracts from several tropical plants, including Antiaris Toxicaria, Picrasma Javanica, Eugenia Caryophyllata, Piper Cubeba, and Cymbopogon Wintwrianus have also been reported to have anti-mosquito effects on subterranean termites. The crude ethanol extract of $S$. Aromaticum and M. Leucadendra had different toxicity effects 
on the subterranean termites $C$. Formosanus even though they were used at the same eugenol-based concentration. Crude extracts from the two plant species may be potentially useful in the development of future termite control products. To avoid environmental pollution, it is very necessary to search for biopesticides that can produce synergistic effects to increase the control effect on termites. This experiment showed that the extract from $S$. Aromaticum leaves contains biologically active compounds with ascertainable effects on subterranean termites C. Formosanus. Gel bait has the potential to be used as a corrective control measure against subterranean termites of type I. Minor, and the consideration of its varying performance will be a key factor in building reliable bait systems to eradicate termites in buildings [21].

The nature of the beauty of wood is the appearance characteristics, which are related to the configuration of the colour, pattern, and texture [16]. Wood conservation practices are carried out to restore and preserve the beautiful nature of wood, such as when these cultural heritage buildings were built in their time [3]. The treatment of furnishing a polychromatic layer to the wooden structure is also one way of conserving material. The polychromatic surface treatment is a popular technique by utilizing pigments in a layer of soil, which is made up of various materials. This method of conservation could be an alternative to maintain the value of historical buildings according to the need to preserve and present their aesthetic intentions $[3,4,25]$. This effort could be implemented on the wood carving as the ornaments of a traditional house of West Kalimantan. This conservation effort can be tested on wood carvings found in historical buildings to reduce or reverse weathering effects due to organisms or nature. If the decay is too severe and efforts to preserve historical characters or architectural prints, carvings, or furniture falter, restorers may consider repair work using the epoxy method. The effort only makes the wood cleaner in appearance, but it will not stop existing spoilage [19].

Wood structures are usually degraded by wood rot fungi and result in a loss of dimensional and structural stability [6]. The human eye easily detects a fungus, only affects the aesthetic appearance, and is easily removed by traditional cleaning protocols; while wood decay fungus often appears (visually) when structural damage is irreversible. The appearance of fungi ("imperfection" / slime molds) is an indicator of the need for immediate consolidation and comprehensive protection of cultural heritage assets to prevent the colonization of specific degradation agents [4]. Fungal staining does not cause loss of strength but results in decreased grades for some wood and is considered unfavourable due to its appearance [19]. The appearance of fungus is the beginning of other damage and will subsequently develop into weathering of the entire structure. Succession is a necessary phenomenon for the biodegradation of wood. If staining risk appears severe, fungicide protection and good drying practices are recommended to produce high-quality cultural heritage restoration [19]. West Kalimantan people basically knew a traditional method for wooden treatment on house construction to drying of material by proper stack placement and airflow.
The best method to prevent termite infestation in the soil is to create wooden structures and constructions in a way that allows conditions to remain dry [19]. The diagnosis formulated after two surveys proved that the durability of wood in service depends more on the maintenance conditions of the building than on the natural resistance of the wood species [26]. Wooden buildings need ongoing maintenance. It is also recommended to treat mold in all parts of the structure where it is impossible to maintain the microclimate and building conditions to achieve a wood moisture content below $20 \%$. Cultural heritage buildings made of wood have natural preservation properties that decrease due to age and environmental factors. One principle is to reuse the former materials, including the damaged ones, as much as possible to secure the guarantee for preserving authenticity [3,4,25]. For wooden structures in the traditional houses of West Kalimantan, recycling old materials is the most significant principle by providing a damage investigation, and figuring out the types, scope, and extent of these damages is essential to understand their causes. In general, protection against subterranean termites and minimizing the rotting process of wood during treatment requires the following activities:

- Clearing all tree stumps and wood waste both under and around the building around the re-construction site.

- Treating the soil with an insecticide and allowing the soil to consolidate before replacing the wood material.

- Covering the foundation of the buildings by a concrete mixture with the height at least 8 inches (about 20 centimetres) up from the ground and setting a sufficient elevation for the buildings' floors.

- Erecting buildings away from land locations with steep slope contours and prepare drains to divert moisture away from buildings.

- Intensive care and treatment to the wood closest to the ground by kept away from contact with soil or moisture sources.

- Preventing damage to the wood in parts of the building from getting wet due to rain, leaks, and condensation by the ventilation and a periodic inspection

\section{CONCLUSION}

Conservation of wooden structures in traditional buildings as an effort to save the cultural heritage architecture in West Kalimantan needs to be fulfilled using chemicals for structures that are too severely decayed through consideration of repair work with epoxy, especially for ornamental parts of the building. Furthermore, the conservation activities as an environmental improvement by cleaning before preservation of buildings; applying insecticides to the soil; and special treatment on certain elements of the building. The conservation of wood materials by using traditional methods in the application of bio-pesticides from local plant extracts and applying environmentally friendly materials, such as salt, as an 
environmentally friendly effort to reduce and eliminate the impact of organisms on buildings. The last is the use of wood which has been specially treated as a substitute material for the structure.

\section{ACKNOWLEDGMENT}

This scientific article has been developed and compiled from the contributions of the first author's thoughts at the National Meeting of the BPP LN DIKTI. The publication of the article has the support from the Directorate General of Resources for Science, Technology, and Higher Education Ministry of Education and Culture of the Republic of Indonesia. Thanks, are also delivered to all colleagues of the Department of Architecture Universitas Tanjungpura for their support to the authors through many discussions to develop scientific knowledge for the article.

\section{REFERENCES}

[1] Y. Suranto, "Identifikasi Kayu Arkeologis Komponen Bangunan M Fort Rotterdam Dalam Rangka Konservasi Kayu Dan Pemugaran Fitur Cagar Budaya," In Seminar Nasional Mapeki XV, vol. 6, pp. 7, 2012.

[2] Z. Zain, "Strategi Perlindungan Terhadap Arsitektur Tradisional Untuk Menjadi Bagian Pelestarian Cagar Budaya Dunia," NALARs, vol. 13, no. (1), 2014.

[3] K. Nitto, Y. Uekita, B. Jiang, S. Oodaira and K. Sato, "Conservation and restoration guidelines for the Omo Sebua in Bawömataluo Village, South Nias, Indonesia," Asian Cultur History, vol. 8, no. (1), pp. 167175, 2016.

[4] T. Tomaszek, "Authenticity and significance in wooden buildings-The problems of conservation of orthodox churches from Poland," ProcediaSocial and Behavioral Sciences, vol. 225, pp. 337-347, 2016.

[5] A.S. Wibowo, "Conservation of wooden architecture: Willingness, support and tradition," Procedia-Social and Behavioral Sciences, vol. 184, pp. 388-393, 2015

[6] P.V. Alfieri, R. García, V. Rosato and M.V. Correa, "Biodegradation and Biodeterioration of Wooden Heritage: Role of Fungal Succession," International Journal of Conservation Science, vol. 7, no. (3), pp. 607 614, 2016.

[7] N. Dalkılıç and A. Nabikoğlu, "Documentation and analysis of structural elements of traditional houses for conservation of cultural heritage in Siverek (Şanlıurfa, Turkey)," Frontiers of Architectural Research, vol. 9, no. (2), pp. 385-402, 2020

[8] E. Maurin and P. Galimard, "Diagnosis off cultural herittage wooden structures: Two case studies," Multidiciplinary Conservation: a Holistic View for Historic Interiors. Joint Interim-Meeting of five ICOM-CC working Group in Rome. Paris: International Council of Museums Committee for Conservation (ICOM-CC), 2010.

[9] M. Sandelowski, J. Leeman, K. Knafl and J.L. Crandell, "Text-in-context: a method for extracting findings in mixed-methods mixed research synthesis studies," Journal of Advanced Nursing, vol. 69 , no. (6), pp. 1428-1437, 2013.
[10] Z. Zain and U.F. Andi, "The intangible characteristics of the two indigenous traditional dwellings in West Kalimantan," ITU Journal of Faculty Archictecture, vol. 17, no. (1), pp. 25-36, 2020.

[11] Z. Zain, "The Ecological Responsive Buildings: Traditional House in the Kapuas Riverside of West Kalimantan," KOMUNITAS: International Journal of Indonesian Society and Culture, vol. 8, no. (2), pp. 295-308, 2016.

[12] Y. Indrayani, M. Muin and T. Yoshimura, "Diversity of tropical plants and their attractant properties for subterranean termite Coptotermes curvignathus," Biodiversitas Journal of Biological Diversity, vol. 18, no. (4), pp. 1353-1357, 2017.

[13] Z. Zain, "Pengaruh Aspek Eksternal Pada Rumah Melayu Tradisional Di Kota Sambas Kalimantan Barat," Jurnal Arsitektur NALARs, vol. 11, no. (2), pp. 101-124, 2012

[14] Y. Indrayani, A. Hikmayanti and Y. Takematsu, "Survey on the infestation of school buildings by termites in Pontianak," Proceeding of The 10th Pacific-Rim Termite Research Group Conference (TRG 10). Kuala Lumpur, Malaysia, 26-28 February 2014.

[15] T.C. Scheffer and A.F. Verrall, Principles for protecting wood buildings from decay (Vol. 190). Department of Agriculture, Forest Service, Forest Products Laboratory, 1979

[16] Y. Suranto, "Aspek kualitas kayu dalam konservasi dan pemugaran cagar budaya berbahan kayu," Konservasi Cagar Budaya Borobudur, vol. 6, no. (1), pp. 87-93, 2012.

[17] K.E. Larsen and N. Marstein, Conservation of historic timber structures. An ecological approach. Riksantikvaren, 2016.

[18] W.W. Wilcox, Decay of wood in structures. California, USA: California Agriculture, 1979

[19] T. Shupe, S. Lebow and D. Ring, Causes and Control of Wood Decay, Degradation \& Stain. Lousiana: Lousiana State University Agricuture Research and an Extention, 2008.

[20] A. Chan, Preservation and Restoration of Timber Heritage Structures. Melbourne: International Specialised Skills Institute, 2011.

[21] Y. Indrayani, T. Yoshimura and Y. Imamura, "A novel control strategy for dry-wood termite Incisitermes minor infestation using a bait system," Journal of Wood Science, vol. 54, no. (3), pp. 220-224, 2008.

[22] Y. Indrayani, M. Muin, C. Adilla and T. Yoshimura, "Short Communication: Attractiveness of subterranean termite Coptotermesformosanus to plant leaf extracts," Biodiversitas, vol. 19 no. (3), pp. 1176-1180, 2018.

[23] Y. Indrayani, Y. Takematsu and T. Yoshimura, "Diversity and distribution of termites in buildings in Pontianak, West Kalimantan, Indonesia," Biodiversitas Journal of Biological Diversity, vol. 18, no. (3), pp. 954-957, 2017.

[24] Y. Indrayani, M. Muin and T. Yoshimura, "Crude extracts of two different leaf plant species and their responses against subterranean termite Coptotermes formosanus," Nusantara Bioscience, vol. 8, no. (2), pp. 226-231, 2016.

[25] S. Palanti, N. Macchioni, R. Paoli, E. Feci and F. Scarpino, "A case study: The evaluation of biological decay of a historical hayloft in Rendena Valley, Trento, Italy," International Biodeterioration \& Biodegradation, vol. 86, pp. 179-187, 2014.

[26] ICOMOS, Principles for the Preservation of Historic Timber Structures". Final draft of GA 2017 6-3-4 - Doctrinal Texts Ver. 30/07/2017. Paris, France: ICOMOS, 2017. 